\title{
Rancangan Pelaksanaan Pembelajaran Dengan Metode Mind Mapping Untuk Meningkatkan Kemampuan Berpikir Kreatif
}

\author{
Restu Ahmad Nugraha Septian ${ }^{1}$, Rien Safrina ${ }^{2}$, Khaerudin $^{3}$, Vina Iasha ${ }^{4}$ \\ Universitas Negeri Jakarta, Indonesia ${ }^{1,2,3,4}$ \\ Email : restu.ahmadnugraha@gmail.com ${ }^{1}$ rsafrina@unj.ac.id ${ }^{2}$ khaerudin.tik@ gmail.com ${ }^{3}$ \\ vina.iasha@gmail.com ${ }^{4}$
}

\begin{abstract}
Abstrak
Penelitian ini bertujuan untuk memahami metode mind mapping dan perannya dalam meningkatkan kemampuan berpikir kreatif siswa. Metode yang digunakan dalam penelitian ini adalah studi pustaka, dimana peneliti mengumpulkan data dari berbagai sumber bacaan terkait pembelajaran yang menggunakan mind mapping dan kemampuan berpikir kreatif. Penelitian difokuskan pada membuat rancangan RPP (Rencana Pelaksanaan Pembelajaran) metode mind mapping, untuk mata pelajaran IPA yang berfokus pada peningkatan kemampuan berpikir kreatif siswa yang mencakup kemampuan menampilkan keaslian (originality), kemampuan menampilkan kelancaran (fluency), dan kemampuan melengkapi penguraian (elaboration). Analisis data adalah deskriptif analisis yang dilakukan dengan membuat catatan kritis, memberi kode kategori, membuat chart, dan memberi stabilo atas bahan-bahan bacaan yang terkait dengan mind mapping dan kemampuan berpikir kreatif. Hasil penelitian menunjukkan bahwa diperlukan RPP yang detail dan komprehensif tentang mind mapping, agar dapat membantu guru dalam mencapai tujuan pembelajaran yang terkait dengan meningkatkan kemampuan berpikir kreatif siswa. Penelitian ini diharapkan dapat menjadi sebuah panduan bagi guru yang akan menerapkan metode mind mapping dalam pembelajaran khususnya pada mata pelajaran IPA di SD.
\end{abstract}

Kata kunci : berpikir kreatif, mind mapping, pembelajaran IPA

\begin{abstract}
The purpose of the study is to examine the mind mapping method and its role in improving students' creative thinking abilities. The method used in this study is a literature study, where researcher collects the data from various reading source related to learning that use mind mapping and creative thinking skills. The study focused on designing the lesson plan (Learning Implementation Plan) that emphasized on mind mapping method, and its role in improving students' creative thinking abilities that display authenticity, fluency, and elaboration. The discussion includes the challenges might be faced in implementing the mind mapping model in the classroom, and the solutions that help teachers to solve the problems. The data analyzed using a descriptive analysis by making critical notes, coding categories, charts, and highlighting the reading materials that are related to mind mapping and critical thinking skills. The results indicate that a detailed and comprehensive lesson plan on mind mapping is necessary in order to help teachers improving their students' ability in creative thinking skills. This study is expected to be a guideline for teachers who will implement the mind mapping model in learning process, especially in science subjects in elementary schools.
\end{abstract}

Keywords : creative thinking, mind mapping, science

Copyright (c) 2020 Restu Ahmad Nugraha Septian, Rien Safrina, Khaerudin, Vina Iasha

$\triangle$ Corresponding author :

Address : Majalengka, Jawa Barat

Email : restu.ahmadnugraha@gmail.com

Phone : 085703146963

ISSN 2580-3735 (Media Cetak)

ISSN 2580-1147 (Media Online)

DOI: https://doi.org/10.31004/basicedu.v4i4.485 
1098 Rancangan Pelaksanaan Pembelajaran Dengan Metode Mind Mapping Untuk Meningkatkan Kemampuan Berpikir Kreatif - Restu Ahmad Nugraha Septian, Rien Safrina, Khaerudin, Vina Iasha DOI: https://doi.org/10.31004/basicedu.v4i4.485

\section{PENDAHULUAN}

Jagat pendidikan sedang hangatnya membahas pembelajaran abad 21. Pembelajaran abad 21 merujuk pada transisi pembelajaran di mana kurikulum yang dirancang saat ini mendorong sekolah untuk mengubah orientasi pembelajaran teacher centered learning (berpusat pada pendidik) menjadi student centered learning (berpusat pada peserta didik). Secara kompetensi pembelajaran abad 21 mencerminkan empat hal, yaitu berpikir kritis, kreativitas, komunikasi, dan kolaborasi. Selain itu, tuntutan dunia masa depan di mana peserta didik harus memiliki kecakapan berpikir dan belajar. Salah satu kecakapan berpikir yang dimaksud adalah berpikir kreatif.

Kemampuan berpikir kreatif sangat penting dimiliki oleh peserta didik. Guna menghadapi tantangan dan permasalahan baik di sekolah maupun dalam kehidupan sehari-hari. Dengan berpikir kreatif, peserta didik dapat mengembangkan pemikirannya untuk melihat permasalahan dari berbagai sudut pandang. Dengan begitu akan menghasilkan berbagai cara dan solusi dalam menyelesaikan masalah tersebut. Kemampuan berpikir kreatif dapat dikembangkan dalam pelajaran di sekolah. Dengan demikian, seharusnya guru dapat menciptakan proses pembelajaran yang menstimulus peserta didik berpikir kreatif.

Permasalahan yang dialami siswa di kelas IV SDN Cigasong I saat mempelajari IPA yaitu siswa mengalami hambatan dalam mengerjakan soal-soal yang menuntut berpikir kreatif. Seperti halnya memecahkan masalah terkait isu-isu lingkungan. Saat memecahkan masalah, siswa mengalami kesulitan dalam menghasilkan solusi, membuat alternatif solusi, serta menguraikan solusi tersebut menjadi jelas dan rinci. Hal tersebut karena pembelajaran yang dilakukan guru masih dominan dengan metode ceramah, yang membuat siswa minim dalam berpikir dan memecahkan masalah. Selain itu, pemberian soal masih identik dengan soal hafalan. Hal tersebut hanya menuntut siswa untuk mengingat materi yang ada di buku atau yang telah disampaikan guru.

Pemilihan metode mind mapping tidak lepas dari relevansinya dengan masalah yang ada yaitu rendahnya kemampuan berpikir kreatif siswa. Mind mapping dapat melatih otak siswa untuk melihat secara menyeluruh/terperinci dan terintegrasi antara logika dan daya khayal siswa (Zahro, Degeng, \& Mudiono, 2018). Kemudian, mind mapping juga dipandang dapat memberikan gambaran (pandangan) menyeluruh terhadap suatu pokok masalah, dapat membantu siswa merencanakan atau membuat pilihan untuk memecahkan suatu masalah dengan cara yang menyenangkan untuk dilihat, dicerna, dan lebih mudah untuk diingat. Mind mapping memiliki beberapa keunggulan, yaitu: 1) dapat mempermudah untuk mengingat sesuatu; 2) memudahkan untuk mengingat dan menghafal akan lebih cepat; 3) kerja otak semakin maksimal; 4) meningkatkan kreativitas, lebih sederhana, dan sangat mudah untuk dikerjakan; 5) mempermudah mendapatkan informasi, ide, dan gagasan untuk dapat dijelaskan. Selain itu, dalam pembelajaran mind mapping siswa dituntut untuk mampu membuat dan mencatat materi pembelajaran kreatif dengan menambahkan variasi kata-kata, 
1099 Rancangan Pelaksanaan Pembelajaran Dengan Metode Mind Mapping Untuk Meningkatkan Kemampuan Berpikir Kreatif - Restu Ahmad Nugraha Septian, Rien Safrina, Khaerudin, Vina Iasha DOI: https://doi.org/10.31004/basicedu.v4i4.485

warna, garis, serta gambar pada selembar kertas kosong putih sehingga mempermudah siswa untuk mengingat materi pembelajaran (Larasati, 2015). Dengan memperoleh informasi yang banyak, akan memudahkan siswa memecahkan masalah secara lancar dan rinci, yang mana hal tersebut merupakan bagian dari berpikir kreatif.

\section{METODE}

Metode yang digunakan dalam penelitian ini yaitu studi pustaka. Melalui metode studi pustaka, peneliti membuat desain rencana pelaksanaan pembelajaran (RPP) untuk meningkatkan kemampuan berpikir kreatif siswa dalam penerapan metode mind mapping pada mata pelajaran IPA materi perubahan lingkungan dan pengaruhnya terhadap lingkungan di kelas IV SD.

Dalam studi pustaka ini, peneliti menggunakan berbagai sumber seperti buku, jurnal ilmiah, majalah, dan sumber dari internet. Proses studi pustaka ini diawali dengan pengumpulan sumber, analisis sumber, dan penarikan kesimpulan. Kajian pustaka berfungsi untuk membangun konsep atau teori yang menjadi dasar studi dalam penelitian (Sujarweni, 2014). Oleh karena itu, semakin banyak sumber yang dikaji maka semakin kuat kesimpulan yang dihasilkan.

Analisis data dilakukan dengan membuat catatan kritis, memberi kode kategori, membuat chart, dan memberi stabilo atas bahan-bahan bacaan yang terkait dengan mind mapping dan kemampuan berpikir kreatif. Kemudian, peneliti melakukan cek silang terhadap data-data yang diperoleh dari buku, jurnal ilmiah, majalah, dan sumber dari internet.

\section{HASIL DAN PEMBAHASAN}

Setelah membaca literatur yang terkait dengan topik penelitian, peneliti mencoba membuat rancangan pembelajaran IPA di SD materi perubahan lingkungan dengan metode mind mapping diharapkan dapat meningkatkan kemampuan berpikir kreatif siswa, terdiri dari tahap membuat mind mapping, membuat RPP perubahan lingkungan, serta tantangan dan solusi. Lebih jelasnya akan dipaparkan sebagai berikut.

\section{Tahap Membuat Mind Mapping}

1. Kerangka Mind Mapping

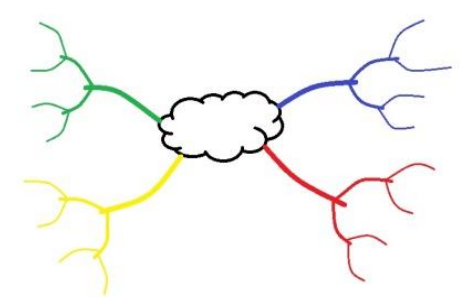

Gambar 1. Kerangka Mind Mapping

Gambar di atas merupakan contoh kerangka mind mapping yang masih kosong. Mind mapping yang kosong memberi gambaran awal pembuatan mind mapping.

2. Bagian-bagian Mind Mapping

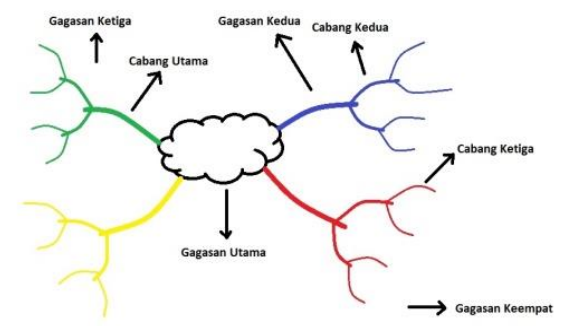

Gambar 2. Bagian-Bagian Mind Mapping Seperti halnya gambar di atas, bagian-bagian mind mapping terdiri dari gagasan utama, cabang utama, gagasan kedua, cabang kedua, 
1100 Rancangan Pelaksanaan Pembelajaran Dengan Metode Mind Mapping Untuk Meningkatkan Kemampuan Berpikir Kreatif - Restu Ahmad Nugraha Septian, Rien Safrina, Khaerudin, Vina Iasha DOI: https://doi.org/10.31004/basicedu.v4i4.485

gagasan ketiga, cabang ketiga, dan gagasan keempat. Sebenarnya untuk jumlah gagasan dan cabang disesuaikan dengan kebutuhan. Setelah membuat kerangka dan mengetahui bagian-bagian mind mapping, selanjutnya tinggal memasukkan kata kunci sesuai dengan materi yang akan dibuat mind mapping.

3. Membuat Mind Mapping Perubahan Lingkungan

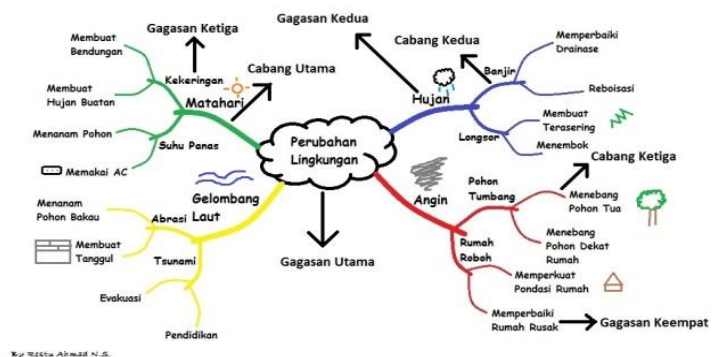

Gambar 3. Mind Mapping Perubahan

Lingkungan

Tahap pertama dalam membuat mind mapping adalah menentukan gagasan utama. Pada mind mapping di atas, gagasan utamanya adalah perubahan lingkungan. Buat satu gambar kreatif di dekat gagasan utama yang mencerminkan perubahan lingkungan. Beri warna pada gambar tersebut agar tampak menarik. Selanjutnya membuat cabang utama. Pada mind mapping di atas, cabang utamanya ada empat yang memancar dari gagasan utama. Dilanjutkan dengan membuat gagasan kedua. Pada mind mapping di atas, gagasan keduanya adalah matahari, hujan, angin, dan gelombang laut. Tempatkan gagasan kedua di atas cabang utama. Buat satu gambar pada masing-masing gagasan kedua yang mewakili dan kreatif. Beri warna pada gambar tersebut agar tampak menarik. Lalu, membuat cabang kedua. Cabang kedua memancar dari gagasan kedua dan lebih tipis dari cabang utama. Kemudian, membuat gagasan ketiga. Pada mind mapping di atas, gagasan ketiganya adalah kekeringan dan suhu panas, banjir dan longsor, pohon tumbang dan rumah roboh, serta abrasi dan tsunami. Tempatkan gagasan ketiga di atas cabang kedua. Buat satu gambar pada masing-masing gagasan ketiga yang mewakili dan kreatif. Beri warna pada gambar tersebut agar tampak menarik. Selanjutnya, membuat cabang ketiga. Cabang ketiga memacar dari gagasan ketiga dan lebih tipis dari cabang kedua. Lalu, membuat gagasan keempat. Pada mind mapping di atas, gagasan keempatnya adalah membuat bendungan dan membuat hujan buatan, menanam pohon dan memakai AC; memperbaiki drainase dan reboisasi, membuat terasering dan menembok; menebang pohon tua dan menebang pohon dekat rumah, memperkuat pondasi rumah dan memperbaiki rumah rusak; serta menanam pohon bakau dan membuat tanggul, evakuasi dan pendidikan. Tempatkan gagasan keempat di atas cabang ketiga. Buat satu gambar pada masing-masing gagasan keempat yang mewakili dan kreatif. Beri warna pada gambar tersebut agar tampak menarik. Pada mind mapping di atas hanya sampai pada gagasan keempat dan cabang ketiga. Hal tersebut agar tidak terlalu rumit berhubung mind mapping ini untuk siswa SD.

\section{Membuat RPP Perubahan Lingkungan}

Merancang RPP harus mengaitkan komponen-komponen RPP dalam satu pengalaman 
1101 Rancangan Pelaksanaan Pembelajaran Dengan Metode Mind Mapping Untuk Meningkatkan Kemampuan Berpikir Kreatif - Restu Ahmad Nugraha Septian, Rien Safrina, Khaerudin, Vina Iasha DOI: https://doi.org/10.31004/basicedu.v4i4.485

belajar. Sebagaimana menurut Permendikbud No. 22 Tahun 2016, salah satu prinsip pengembangan RPP adalah adanya keterkaitan dan keterpaduan antara KD, materi pembelajaran, kegiatan pembelajaran, indikator pencapaian kompetensi, penilaian, dan sumber belajar dalam satu keutuhan pengalaman belajar.

Setiap tahap pembelajaran dalam RPP penelitian ini didesain khusus terkait lingkungan. Seperti pada kegiatan awal, siswa berdoa untuk kebaikan lingkungan dan terhindar dari bencana alam, serta menyanyikan lagu "Memandang Alam" ciptaan Pak Kasur. Lalu, pada kegiatan inti diawali dengan penayangan video perubahan lingkungan, tanya jawab terkait perubahan lingkungan, dan pembuatan mind mapping tentang perubahan lingkungan, seperti halnya pada Gambar 3. Mind Mapping Perubahan Lingkungan, serta dilanjutkan dengan tes kemampuan berpikir kreatif dengan soal mengenai perubahan lingkungan. Kemudian, pada kegiatan akhir siswa diberi tindak lanjut untuk mengamati lingkungan di sekitar rumahnya. Semua tahap pembelajaran tersebut tersaji dalam satu keutuhan pengalaman belajar.

\section{Tantangan dan Solusi dalam Menerapkan RPP}

\section{Perubahan Lingkungan}

Dalam menerapkan RPP tersebut, ada beberapa tantangan dan solusi yang harus diperhatikan guru, di antaranya:

1. Tantangan

a. Waktu

Menerapkan RPP dengan metode mind mapping membutuhkan waktu yang cukup lama. Misalnya, pada kegiatan inti guru harus memperkenalkan terlebih dahulu apa itu mind mapping sampai siswa benar-benar paham, agar anak tidak bingung ketika disuruh membuat mind mapping. Selain itu, berhubung RPP ini untuk siswa SD, maka akan membutuhkan waktu juga dalam proses pengondisian kelas.

b. Alat dan Bahan

Alat dan bahan membuat mind mapping terdiri dari kertas kosong bisa kertas HVS atau kertas gambar, pensil dan penghapus, serta spidol warna. Tanpa alat dan bahan maka pembuatan mind mapping tidak bisa dilaksanakan. Apalagi RPP ini diterapkan untuk siswa SD, pasti sering terjadi lupa bawa, hilang, males, belum beli, dst.

c. Menentukan Kata Kunci

Membuat mind mapping tidak seperti halnya membuat rangkuman biasa dengan mengumpulkan kalimat penting. Namun, yang dibutuhkan adalah menentukan kata kunci. Mungkin bagi siswa SMP atau SMA menentukan kata kunci tidaklah menjadi masalah, namun bagi siswa SD masih perlu bimbingan dan tuntunan dalam menentukan kata kunci.

\section{Solusi}

a. Waktu

Solusi yang dapat dilakukan guru dalam mengatasi masalah waktu yang lama dalam penerapan RPP tersebut yaitu guru harus membuat perencanaan yang matang sebelum mengajar. Hal apa saja yang dapat mengganggu jalannya pembelajaran agar dibuat rencana langkah tindakannya. Selain 
1102 Rancangan Pelaksanaan Pembelajaran Dengan Metode Mind Mapping Untuk Meningkatkan Kemampuan Berpikir Kreatif - Restu Ahmad Nugraha Septian, Rien Safrina, Khaerudin, Vina Iasha DOI: https://doi.org/10.31004/basicedu.v4i4.485

itu, guru dapat menyederhanakan atau memangkas kegiatan-kegiatan yang dapat menyita waktu lama. Misalnya, sebelum mulai proses pembelajaran anak sudah dikenalkan mind mapping.

b. Alat dan Bahan

Solusi yang dapat dilakukan guru dalam mengatasi masalah alat dan bahan adalah dengan selalu mengingatkan siswa untuk membawa alat dan bahan membuat mind mapping. Selain itu, untuk mengantisipasi jika ada anak yang tidak membawa alat dan bahan, guru harus selalu siap sedia membawa alat dan bahan cadangan.

c. Menentukan Kata Kunci

Kemampuan menentukan kata kunci dapat dimiliki siswa apabila mereka sudah paham dan terbiasa melakukannya. Sehingga yang menjadi tugas guru adalah bagaimana mengajarkan siswa dalam hal ini siswa SD untuk mampu menentukan kata kunci, serta membiasakannya dalam setiap proses pembelajaran.

Berdasarkan RPP tersebut, pembelajaran dengan metode mind mapping dapat meningkatkan kemampuan berpikir kreatif siswa tergambar dalam kegiatan menentukan kata kunci yang menuntut kemampuan keaslian (originality), menghasilkan banyak gagasan turunan yang menuntut kemampuan kelancaran (fluency), dan menguraikan gagasan utama menjadi gagasan turunan yang menuntut kemampuan penguraian (elaboration). Ketiga kemampuan tersebut merupakan aspek kemampuan berpikir kreatif menurut Guilford yaitu kelancaran (fluency), keaslian (originality), dan penguraian (elaboration).

Selain dari argumen tersebut, banyak penelitian terdahulu yang mengatakan bahwa metode mind mapping dapat meningkatkan kemampuan berpikir kreatif siswa, seperti halnya penelitian berikut ini:

Penelitian yang berjudul "Penerapan metode mind mapping untuk meningkatkan kreativitas pada pembelajaran pendidikan kewarganegaraan di kelas VI MI" (Latifah \& et all, 2020). Hasilnya adalah metode mind mapping dapat meningkatkan kreativitas siswa pada pembelajaran pendidikan pancasila dan kewarganegaraan. Penelitian ini memiliki kesamaan dengan penelitian peneliti yaitu metode mind mapping untuk meningkatkan kreativitas siswa di MI/SD.

Lalu, penelitian yang berjudul "Penerapan metode mind mapping untuk meningkatkan kemampuan berpikir kreatif siswa sekolah dasar" (Ananda, 2019). Hasilnya adalah penggunaan $m$ etode mind mapping dapat meningkatkan kemampuan berpikir kreatif di kelas V SDN 018 Langgini Bangkinang Kota. Penelitian ini memiliki kesamaan dengan penelitian peneliti yaitu metode mind mapping untuk meningkatkan berpikir kreatif siswa di SD.

Kemudian, penelitian yang berjudul "Peningkatan keterampilan berpikir kreatif siswa kelas 5 menggunakan model mind mapping" (Wulandari \& Krisma, 20s19). Hasilnya adalah adanya peningkatan keterampilan berpikir kreatif siswa menggunakan model mind mapping. Penelitian ini memiliki kesamaan dengan 
1103 Rancangan Pelaksanaan Pembelajaran Dengan Metode Mind Mapping Untuk Meningkatkan Kemampuan Berpikir Kreatif - Restu Ahmad Nugraha Septian, Rien Safrina, Khaerudin, Vina Iasha DOI: https://doi.org/10.31004/basicedu.v4i4.485

penelitian peneliti yaitu mind mapping untuk meningkatkan berpikir kreatif siswa di SD.

\section{SIMPULAN}

Pembelajaran dengan metode mind mapping dapat meningkatkan kemampuan berpikir kreatif siswa, tergambar dalam kegiatan menentukan kata kunci yang menuntut kemampuan keaslian (originality), menghasilkan banyak gagasan turunan yang menuntut kemampuan kelancaran (fluency), dan menguraikan gagasan utama menjadi gagasan turunan yang menuntut kemampuan penguraian (elaboration). Begitupun dengan pendapat ahli dan penelitian sebelumnya yang terkait dengan topik penelitian, bahwa metode mind mapping dapat meningkatkan kemampuan berpikir kreatif siswa. Namun, merancang pembelajaran mind mapping itu tidak mudah. Guru harus memahami bagaimana proses membuat mind mapping, merancang RPP khusus mind mapping, serta memperhatikan tantangan dalam penerapannya seperti manajemen waktu, penyediaaan alat dan bahan, serta mengajarkan kepada siswa bagaimana menetukan kata kunci.

\section{DAFTAR PUSTAKA}

Ananda, R. (2019). Penerapan Metode Mind Mapping untuk Meningkatkan Kemampuan Berpikir Kreatif Siswa Sekolah Dasar.

Larasati, I. (2015). Penerapan Problem Based Learning dengan Mind Mapping untuk Meningkatkan Hasil Belajar Siswa pada Materi Kelarutan dan Hasil Kali Kelarutan Kelas XI IPA di SMA Negeri 1 Jakenan. Retrieved from https://lib.unnes.ac.id/22479/

Latifah, A., \& et all. (2020). Penerapan Metode Mind Mapping untuk Meningkatkan Kreativitas pada Pembelajaran Pendidikan
Kewarganegaraan di Kelas VI MI.

Sujarweni, V. W. (2014). Metodologi Penelitian. Yogyakarta: Skripta Media Creative.

Wulandari, M., \& Krisma. (2019). Peningkatan Keterampilan Berpikir Kreatif Siswa Kelas 5 Menggunakan Model Mind Mapping.

Zahro, F., Degeng, I. N. S., \& Mudiono, A. (2018). Pengaruh Model Pembelajaran Student Team Achievement Devision (STAD) dan Mind Mapping terhadap Hasil Belajar Siswa Kelas IV Sekolah Dasar. Premiere Educandum, Vol 8 . 